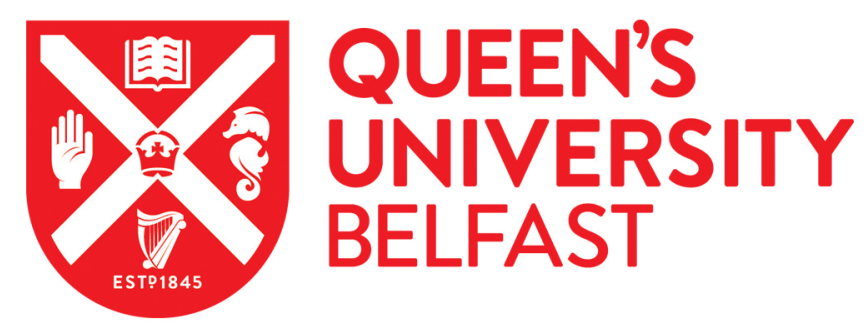

\title{
Changes in epilithic biomasses and invertebrate community structure over a deposit metal concentration gradient in upland headwater
} streams

Macintosh, K. A., \& Griffiths, D. (2015). Changes in epilithic biomasses and invertebrate community structure over a deposit metal concentration gradient in upland headwater streams. Hydrobiologia, 760(1), $159-169$. https://doi.org/10.1007/s10750-015-2323-0

Published in:

Hydrobiologia

Document Version:

Peer reviewed version

Queen's University Belfast - Research Portal:

Link to publication record in Queen's University Belfast Research Portal

\section{Publisher rights}

Copyright Springer International Publishing Switzerland 2015.

The final publication is available at Springer via http://dx.doi.org/10.1007/s10750-015-2323-0.

\section{General rights}

Copyright for the publications made accessible via the Queen's University Belfast Research Portal is retained by the author(s) and / or other copyright owners and it is a condition of accessing these publications that users recognise and abide by the legal requirements associated with these rights.

Take down policy

The Research Portal is Queen's institutional repository that provides access to Queen's research output. Every effort has been made to ensure that content in the Research Portal does not infringe any person's rights, or applicable UK laws. If you discover content in the Research Portal that you believe breaches copyright or violates any law, please contact openaccess@qub.ac.uk. 
1 Changes in epilithic biomasses and invertebrate community structure over a deposit metal concentration

2 gradient in upland headwater streams

3

4 Katrina Ann Macintosh ${ }^{\mathrm{a}, *}$. David Griffiths ${ }^{\text {a }}$

$5 \quad$ a School of Environmental Sciences, University of Ulster, Coleraine, U.K. BT52 1SA

6

$7 \quad *$ Corresponding author:

8 E-mail address: ka.macintosh@ulster.ac.uk

$9 \quad$ Tel.: +44 (0) 2870124426

10 Fax: +44 (0) 2870124911 


\section{Abstract}

12 Stream bed metal deposits affect the taxon richness, density and taxonomic diversity of primary and secondary

13 producers by a variety of direct or indirect abiotic and biotic processes but little is known about the relative

14 importance of these processes over a deposit metal concentration gradient. Inorganic matter (IM), algal, and

15 non-photosynthetic detrital (NPD) dry biomasses were estimated for 10 monthly samples, between 2007 and

16 2008, from eight sites differing in deposit density. Invertebrate abundance, taxon richness and composition were

17 also determined. Relations between these variables were investigated by canonical correspondence analysis

18 (CCA), generalized estimating equation models and path analysis. The first CCA axis correlates with deposit

19 density and invertebrate abundance, with lumbriculids and chironomids increasing in abundance with deposit density and all other taxa declining. Community structure changes significantly above a deposit density of

21 approximately $8 \mathrm{mg} \mathrm{cm}^{-2}$, when algal biomass, invertebrate richness and diversity decline. Invertebrate richness and diversity were determined by direct effects of NPD biomass and indirect effects of IM. Algal biomass only had an effect on invertebrate abundance. Possible pH, oxygen, food and ecotoxicological effects of NPD biomass on the biota are discussed.

\section{Keywords}

27 Metal deposits · Invertebrate richness and composition · Algal biomass · Non-photosynthetic detrital biomass · Direct and indirect pathways 
Deposits of iron hydroxide in surface waters have been documented globally (Niyogi et al. 1999; Prange 2007;

Neal et al. 2008) and are frequently reported in post-industrial landscapes impacted by acid mine drainage

(Younger 2001; Kimball et al. 2002; Mayes et al. 2008). Stream metal deposits are also found in non-industrial, often upland, catchments with limited anthropogenic activity (Macintosh \& Griffiths, 2013; 2014). In impacted areas metal rich precipitates are ubiquitous and envelop benthic habitats, with direct and indirect ecosystem effects. The deposits potentially have harmful effects on algae, invertebrates and fish (Vuori 1995; Jarvis \& Younger 1997).

Stream bed deposits, which are rich in iron $(\mathrm{Fe})$, manganese $(\mathrm{Mn})$ and aluminium $(\mathrm{Al})$, are associated with reductions in the species richness and density of periphyton (McKnight \& Feder 1984; Sheldon \& Skelly 1990; Wellnitz et al. 1994; Wellnitz \& Sheldon 1995; Hill et al. 2000; Verb \& Vis 2000) and macroinvertebrates (Dills \& Rogers 1974; Greenfield \& Ireland 1978; Letterman \& Mitsch 1978; Scullion \& Edwards 1980; McKnight \& Feder 1984; Rasmussen \& Lindegaard 1988; Wellnitz et al. 1994; Clements et al. 2000; Hirst et al. 2002).

Community composition also changes with increasing metal concentration and deposit density, with the reduction/loss of Ephemeroptera, Plecoptera and Trichoptera (EPT) species and dominance by chironomids and oligochaetes (Letterman \& Mitsch 1978; Scullion \& Edwards 1980; Woodcock \& Huryn 2005; Bott et al. 2012). Fish abundance and diversity are also reduced in metal-enriched streams (Mulholland et al. 1992; Vuori 1995). Many of these studies have been conducted in waters affected by acid mine drainage but the faunal effects are similar in circumneutral streams (Greenfield \& Ireland 1978; Rasmussen \& Lindegaard 1988; Clements et al. 2000; Hirst et al. 2002). Hence metal deposits can affect all trophic levels in streams: some authors (Mulholland et al. 1992; Clements et al. 2000) have associated these changes with alterations in ecosystem function, with fewer grazers and filterers in Fe-rich streams. The (physiological) effects of Al on fish survival are well documented (Mason 1996); toxic effects have also been recorded for Fe and Mn (Peuranen et al. 1994; Nyberg et al. 1995; Stubblefield et al. 1997; Dalzell \& Macfarlane 1999; Verberk et al. 2012).

Metal deposition in stream ecosystems is driven by a variety of physical, chemical and biological processes but little is known about their relative importance. The redox processes involved in Fe mobilisation and deposition are well understood (Stumm \& Morgan 1996), as is the effect of $\mathrm{pH}$ on the richness and composition of stream organisms (Townsend et al. 1983; Mulholland et al. 1992; Layer et al. 2013). The role of 
biological processes has been less studied. Metal-oxidising bacteria are significant biogenic agents (Crerar et al. 1979; Konhauser 1998; Tebo et al. 2004; Emerson et al. 2010). Stream bed organic matter can be partitioned into phototrophic (algal) and non-photosynthetic detrital (NPD) components: NPD consists of bacteria, fungi, extracellular biofilms and detritus of terrestrial or aquatic origin (Ledger \& Hildrew 1998; Carr et al. 2005). Macintosh \& Griffiths (2014) showed that deposit concentrations were influenced by NPD biomass and tentatively concluded that microbial lithotrophic activity was a likely agent of metal deposition in the streams studied.

While there are exceptions (e.g. Bott et al. 2012), previous studies have tended to focus on deposit effects on a single trophic level: in this study a more holistic approach is taken. We partition the stream bed deposit into inorganic matter (IM), algal and NPD components and examine corresponding differences in invertebrate richness, abundance and composition over spatial and temporal gradients. Specifically we investigate: (1) If deposit density affects algal abundance and invertebrate composition over a deposit metal concentration gradient. (2) Whether food availability determines invertebrate abundance and composition. Algae are an important food source for many aquatic invertebrates (Layer et al. 2013). Hence increasing deposit metal concentrations should have a negative impact on algal biomass which, in turn, will have implications for invertebrate assemblages. (3) The relative importance of direct and indirect effects of the deposit variables (IM, NPD and algal biomasses) in determining invertebrate abundance, diversity and biotic scores.

\section{Materials and Methods}

Study area

The analyses presented here are based on eight stream sites located within the Sperrin Mountains, Northern Ireland: sampled monthly from November 2007 to September 2008, high flows in January prevented adequate sample collection. Spatial survey data from 32 Sperrin Mountains sites, collected on one sampling occasion in April 2007, were used to confirm the algal and NPD deposit correlations (Macintosh \& Griffiths, 2014).

Study sites were small, 1-2m wide, first order upland streams and tributaries of the Glenelly and Glenlark rivers, which are part of the Owenkillew catchment. All but two of these sites drained separate areas. Streamflow tended to be 'flashy', with rapid fluctuations between high and low flow discharge (see Macintosh \& Griffiths 2013; 2014 for site locations and general environmental information).

The sites were chosen to represent a range of metal deposit concentrations. All streams were located on open moorland, had well-oxygenated water and stony substrata: no aquatic macrophytes were observed. Sites 
lack anthropogenic interference and are not impacted by mining activities. The benthic chlorophyll $a$ (Chla) and phosphorus (P) concentrations indicate that these streams are oligotrophic (Dodds et al. 1998).

\section{Sampling and laboratory analysis}

Each of the eight sites was visited monthly to collect water, deposit and invertebrates samples. On each sampling occasion, seven stream bed stones were randomly removed from each site and bagged individually for the analysis of deposit composition (Fe, $\mathrm{Mn}, \mathrm{Al}$ and $\mathrm{P}$ concentration, organic matter (OM) and IM content) and Chla concentration. Deposit material on the upper stone surface was removed by spatula, brush and rinsing with Millipore Milli-Q grade water. Depending upon density, the material from two to three stones was amalgamated and dried at $105^{\circ} \mathrm{C}$ until there was no further weight loss.

Inorganic matter was determined as the material remaining after ashing deposit samples for 1 hour in a muffle furnace at $550^{\circ} \mathrm{C}$ and $\mathrm{OM}$ as the loss-on-ignition (Lamberti \& Resh 1985). Inorganic matter and deposit metal concentrations were strongly correlated with total deposit density $(r=0.68-0.98, n=80, P<0.001)$ : inorganic matter comprised on average 67\% of deposit (range 38-93\%). Deposit material consisted of epilithic algae and 'ochre rich sludge' made up of detritus, fungi/bacteria and metal hydroxides: silt levels were low as a result of the flashy nature of the upland stream systems and the preponderance of peat in the catchment (Macintosh KA unpublished observation). Deposit density was calculated as the dry mass of material per unit surface area, the latter determined by covering the exposed stone surface with aluminium foil which was then weighed.

Metal concentration in the deposit material was determined by sequential acid digestion: hydrofluoric acid was used to break down silicates, and nitric and perchloric acids to oxidise organics. After acid treatment, deposit Fe, Mn, Al and P concentrations were measured by spectrometry (Macintosh \& Griffiths (2013) using 2, 4, 6-tripyridyl-1, 3, 5-triazine, formaldoxime, pyrocatechol violet and molybdate-antimony methods respectively (HMSO 1978a; 1978b; 1980; Murphy \& Riley 1958; 1962). Blanks (Millipore Milli-Q) and standards were included, in triplicate, for each chemical determinand.

Epilithic algal Chla concentrations were determined following the procedure of Marker et al. (1980), after cold extraction in the dark at $4^{\circ} \mathrm{C}$. Published data on ash free dry weight (AFDW) and Chla concentrations of periphyton from streams without Fe deposits (Clark et al. 1979; Weitzel et al. 1979; Biggs \& Close 1989; Biggs 1996; Hill et al. 2000; Pizarro \& Vinocur 2000; Carpenter 2003) were compiled and the autotrophic index, an indicator of change in the relative importance of heterotrophic and autotrophic biomasses (Rice et al. 
2012), calculated as AFDW/Chla. Indices below 200 were taken as indicative of sites where production was dominated by photosynthetic rather than by lithotrophic activity. From these low autotrophic index sites the AFDW attributable to photosynthetic organisms (algal biomass), was estimated from measured deposit Chla concentrations $\left(\log\right.$ AFDW $\left.=2.016+1.043 \pm 0.026 \operatorname{logChla}, r^{2}=0.98, n=37\right)$. Deposit density was partitioned into IM, algal and NPD components. In the absence of direct measures, the difference between algal biomass and the corresponding OM values was used as an estimate of NPD biomass (Macintosh \& Griffiths, 2014).

On each sample date, invertebrates were collected in non-pool habitat by a single, area-standardised kick sample, covering $100 \mathrm{~cm}$ length of stream bed $\mathrm{x}$ net width $(25 \mathrm{~cm})$, to give a semi-quantitative estimate of density (Rice et al. 2012). The animals were identified to family level (Croft 1986) and numbers counted. Published diet data (e.g. Mellanby 1963; Merritt \& Cummins 1996; Mihuc 1997; http://water.epa.gov/scitech/monitoring/rsl/bioassessment/app_b-1.cfm) were used to allocate taxa to shredder, collector-gatherer, collector-filterer, herbivore and predator functional feeding groups.

\section{Statistical analyses}

The relation between in-stream deposit composition variables and invertebrate abundances was investigated by canonical correspondence analysis (CCA), as implemented in PC-Ord v5 (McCune \& Mefford 2006). Six families, represented by fewer than 16 individuals (over 80 samples) and therefore judged as rare taxa, were omitted from the analysis. Potentially important environmental variables that might affect invertebrates (\% dissolved oxygen (DO), temperature, $\mathrm{pH}$, IM, deposit metal and biomass component concentrations) were used. To test whether food availability influenced invertebrate abundance, correlations between algal and NPD biomasses and invertebrate family abundances over the sampling period were calculated. To test for a herbivore effect, the three ephemeropteran families were combined into a mayfly group.

The monthly data are temporally pseudoreplicated and therefore potentially correlated within sites. These data were analysed by generalized estimating equation (GEE) models, which are designed to deal with correlated data (Garson 2013), using SPSSv21. The models, fitted assuming a normal distribution and identity link function, were estimated using the model-based estimator because the number of sites was less than 10 . The within-site correlation structure needs to be specified in GEE models. As indicated by quasi-likelihood under independence criterion (QIC) values, the independent option, that is assuming that successive measurements are uncorrelated, gave consistently better fits than first-order autoregressive or unstructured models. If the deposit increasingly influences biotic structure one would expect a non-linear relationship, the simplest of which to 
model is the quadratic. The fits of quadratic and linear deposit density predictors were compared by the corrected version of QIC (QICC), to test if the responses were non-linear: the greater the difference in QICC statistics between models the stronger the evidence for a particular model. QICC statistics are interpreted in the same way as the more familiar AIC statistics (Burnham \& Anderson 1998).

Path analysis (Quinn \& Keogh 2002) was used to test all direct and indirect paths from IM, NPD and algal biomasses to the target invertebrate variable. We are unaware of any path analysis procedure that allows for temporally pseudoreplicated data and so these results need to be treated with some caution. However, the finding that the best fit GEE models were obtained with uncorrelated (independent) within site values suggests that the path analysis results are realistic. Various invertebrate measures were calculated. Taxon richness was estimated as the number of families while Shannon diversity, evenness and Berger-Parker indices, which take abundances into account, were calculated as measures of invertebrate diversity, evenness and dominance respectively (Magurran 1988). ASPT (average score per taxon), a measure of the sensitivity of the invertebrate fauna to organic pollution (oxygen stress), was calculated from faunal composition at each site.

All variables, except temperature, $\mathrm{DO}$ and $\mathrm{pH}$, were $\log _{10}$ transformed to normalise the data. Non-linear lines were fitted to the physical, chemical and biological variable data using locally weighted scatterplot smoothers (LOWESS) because these do not impose a functional form on the relationship.

\section{Results}

Medians and ranges of deposit and biotic variables are summarised in Table 1: the variables vary by 2-4 orders of magnitude across sites and season. Seasonal trends in physical, chemical and biological variables are also shown in Online Resource1. Some variables, for example algal biomass and invertebrate abundance show marked seasonal changes while others, such as $\mathrm{pH}$, metal concentrations, and NPD biomass, are less variable.

The first three axes of the CCA had significantly greater taxon-environment correlations than expected from 999 randomizations $(P<0.001)$ and explained 14, 11 and 7\% respectively of the variance. Important chemical determinants of deposition, $\mathrm{pH}$ and $\mathrm{DO}$, were weakly or non-significantly correlated with all axes (Table 2). Episodic low pH can potentially affect the biota but of nine invertebrate taxon abundance and diversity measures only trichopteran abundance showed a significant correlation with minimum site $\mathrm{pH}$. There were strong positive correlations of deposit IM and metal concentrations with the first axis while invertebrate richness and diversity measures were negatively correlated with this axis. Lumbriculids and chironomids showed positive correlations with the first axis whereas significant negative relationships were found for all 
stonefly families and sericostomatids (Fig. 1, Table 2). Mayflies were negatively correlated with the second axis, which was correlated with DO (+), P (+) and temperature (-). Gammarids (+), perlids (+) and chironomids (-) were correlated with the third axis, which was negatively correlated with algal biomass.

There were only three significant correlations between algal biomass and the abundance of particular families. All were positive, but none of the three families (leuctrids, nemourids and chironomids) would normally be classified as herbivores. In contrast, 9/15 correlations with NPD biomass were significant, eight of which were negative: only lumbriculid abundance was positively correlated with NPD biomass $(r=0.54$, $P<0.001)$. The number of Plecoptera declined with increasing deposit density, IM content and NPD biomass, but increased with algal biomass $(r=-0.38,-0.38,-0.36,0.34$ respectively, all $P<0.01)$ : there were no correlations for Ephemeroptera and Trichoptera.

While NPD biomass rose log-linearly with deposit density, algal biomass and hence the autotrophic index, increased to a deposit density of approximately $8 \mathrm{mg} \mathrm{cm}^{-2}$ before declining (Fig. 2a, Table 3). The spatial survey sites, which were not pseudoreplicated, also showed a non-linear (quadratic) relation for algae and a linear rise for NPD biomass with deposit density ( $r=0.40,0.68$ respectively). While there was no overall relation between algal and NPD biomasses $(r=0.07, n=75, P>0.5)$, above $8 \mathrm{mg} \mathrm{cm}^{-2}$ there was a negative relationship ( $r=-0.67, n=34, P=0.05$ ), consistent with a potential competitive effect. As expected from the deposit density - deposit P relationship ( $r=0.69)$, NPD biomass increased linearly with deposit P concentration but algal biomass showed a significant, dome-shaped, relationship (Table 3) i.e. algal biomass was lower in the most P-rich deposits.

ASPT and taxon richness showed no trends until deposit densities reached $8 \mathrm{mg} \mathrm{cm}^{-2}$ and declined at higher concentrations (Fig. 2b, c), but invertebrate density declined over the whole range (Table 3). Neither Berger-Parker dominance nor dominance measured as equitability (not shown) varied with deposit density. Path analyses explained only 3-19\% of the variation but invertebrate richness, abundance (Fig. 3), and composition measures showed similar responses to direct and indirect effects (Table 4), with NPD effects strongest and algal effects weakest. IM indirect effects were stronger than direct effects, whereas the NPD direct effects were stronger than indirect ones. Biotic scores, abundance, taxon richness and diversity declined and dominance increased with IM and NPD. These effects are consistent with the predominantly negative correlations between NPD biomass and taxon abundance noted above. Most of the indirect effects of IM were through NPD rather than algal biomass, e.g. for number of individuals, path coefficients via NPD and algal 
biomass are $-0.44(0.871 *-0.506)$ and $0.04(0.116 * 0.366)$ respectively. Invertebrate abundance was correlated

with algal biomass: as expected for a food chain effect this correlation was direct and positive.

\section{Discussion}

213 Results from our study support the findings of previous research that stream bed metal deposits reduce invertebrate taxon richness, abundance and diversity: mayfly and stonefly families were most affected, and oligochaetes and chironomids least. Top-down processes seem unlikely to account for these patterns since none of the study sites supported fish populations (Griffiths, D. unpublished observations) and there was no correlation between invertebrate predator and other invertebrate abundances.

The changes in NPD, algal and invertebrate relations at a deposit density of approximately $8 \mathrm{mg} \mathrm{cm}^{-2}$ are consistent with negative food supply, chemical, and/or ecotoxicological effects of the deposit material. Aluminium is generally regarded as more toxic than Fe and Mn (Hirst et al. 2002), both of which can have toxic effects (Maltby \& Crane 1994). Fe affects the survival and feeding activity of some invertebrates (Gerhardt 1992; Maltby \& Crane 1994; Wellnitz et al. 1994). Fe uptake can occur from ingestion of metals whilst feeding, thereby reducing energy intake (Smock 1983; Gerhardt 1993; Maltby \& Crane 1994; Wellnitz et al. 1994), and varies with feeding method, with indiscriminate feeders and filterers tending to have higher body concentrations than predators (Gerhardt 1993; Wellnitz et al. 1994; Hünken \& Mutz 2007). Some invertebrates are affected by metal deposition on respiratory surfaces: the generally high sensitivity of mayfly larvae to Fe-rich deposits is consistent with an Fe precipitation effect on respiratory surfaces (Gerhardt 1992). The path analyses showed that NPD exerted direct negative effects on invertebrate richness, composition and diversity, while the negative effects of IM were indirect and driven by NPD. However, the absence of direct effects for IM suggests that the metals did not have direct ecotoxicological effects.

There was no evidence for an indirect negative effect of NPD biomass on invertebrate abundance via algal abundance (path coefficient $-0.51 * 0.07=0.04$ ), that is for NPD to determine invertebrate abundance and composition by reducing algal populations, or by being less nutritious than algae. However, the significant positive path coefficient (0.37) of algae on invertebrate abundance does suggest a food supply effect, although there was no correlation between mayfly numbers, the most likely group of herbivores, and algal biomass. Layer et al. (2013) have shown changes in the importance of detritus and algae with increasing $\mathrm{pH}$ and corresponding changes in invertebrate richness, abundance and trophic composition. Identification of diet from literature sources is potentially misleading given the considerable spatial and temporal variation observed (Lamberti \& 
Moore 1984; Mihuc 1997). For example, while most sources identify nemourid stoneflies as collector-gatherers,

Ledger \& Hildrew (2000) showed that in at least some acid streams they feed, in part, on algae. From functional feeding groups identified from published data, collector-gatherers had positive and significantly different scores on CCA axis 1, a deposit-density axis, from the other feeding groups. 1999; Clements et al. 2000; Ledger \& Hildrew 2005) but, as we found, not all orders always contribute to this relation (not stoneflies, Rosemond et al. 1992; not caddis, Malmqvist \& Hoffsten 1999; not mayflies, Dsa et al. 2008).

Acidity generally has a marked effect on species richness and the composition of stream bacteria, algae, invertebrates and fish (e.g. Townsend et al. 1983; Mulholland et al. 1992; Rosemond et al. 1992; Ledger \& Hildrew 2005; Layer et al. 2013). Despite our sites covering a similar pH range, we found no effects on deposit density, algal or NPD biofilm biomasses (Macintosh \& Griffiths, 2014), or invertebrate community indices, consistent with these variables being determined by other in-stream factors.

The stream bed was blanketed by a bright orange mat at the most deposit-rich sites in our study. Sheath/stalk production by chemolithoautotrophs, frequently associated with metal deposits (Ghiorse 1984), can stabilise the deposit matrix and decrease oxygen concentration within the deposit (Emerson et al. 2010; Roden 2012). The deposits potentially reduce light levels for benthic primary producers, and consequently oxygen production by photosynthesis, and can also bind phosphorus (Sheldon \& Wellnitz 1998; Withers \& Jarvie 2008; Rentz et al. 2009). The observed decline in algal biomass at high phosphorus concentrations supports the latter possibility while the decline in ASPT scores above a threshold deposit density is consistent with a negative effect on oxygen concentration.

\section{Conclusion}

263 In our study, community structure changes above a deposit density of about $8 \mathrm{mg} \mathrm{cm}^{-2}$, when algal biomass, invertebrate richness and diversity decline. The changes noted in invertebrate richness and composition are consistent with known responses to environmental stress (Rosenberg \& Resh 1993), with lumbriculids and chironomids increasing in abundance and all other taxa declining. Previously reported responses in invertebrate species richness and composition tend only to be found when $\mathrm{pH}$ drops below 6 (Sutcliffe \& Hildrew 1989; 
268 Mason 1996). However, our study streams were circumneutral (median pH 6.7) and there was little evidence

269 that episodes of low pH affected invertebrate abundance and composition.

Metal deposits blanket the stream bed, reduce oxygen concentrations therein and favour invertebrates

271 with low biotic scores, thereby negatively influencing species composition. Deposit accumulations are also

272 known to affect light penetration, reducing algal biomass above a threshold density, and thus influence

273 invertebrate abundance. This essentially correlative study has addressed important questions regarding the

274 direct and indirect effects of metal deposition on upland headwater stream community structure, particularly

275 with regard to changes in algal biomass, invertebrate richness and diversity. Confirmation of its conclusions will

276 require further analysis and more detailed measurements of oxygen concentrations and the distributions of algae,

277 bacteria/fungi and invertebrates within the deposits.

278

279 Acknowledgements

280 Katrina Macintosh would like to thank the funding and facilities provided for this study by a Department for

281 Employment and Learning studentship at the University of Ulster. We are grateful to Joerg Arnscheidt, Tom

282 Bott, Steve Ormerod and a referee for helpful comments on earlier drafts of the manuscript. 
Biggs, B. J. F., 1996. Patterns in benthic algae of streams Algal ecology: freshwater benthic ecosystems. Academic Press, San Diego, 31-56.

Biggs, B. J. F. \& M. E. Close, 1989. Periphyton biomass dynamics in gravel bed rivers: the relative effects of flows and nutrients. Freshwater Biology 22: 209-231.

Bott, T. L., J. K. Jackson, M. E. McTammany, J. D. Newbold, S. T. Rier, B. W. Sweeney \& J. M. Battle, 2012. Abandoned coal mine drainage and its remediation: impacts on stream ecosystem structure and function. Ecological Applications 22: 2144-2163.

Burnham, K. P. \& D. R. Anderson, 1998. Model selection and inference: a practical information-theoretic approach. Springer-Verlag, New York.

Carpenter, K. D., 2003. Water-quality and algal conditions in the Clackamas River Basin, Oregon, and their relations to land and water management US Geological Survey Water-Resources Investigations Report

Carr, G. M., A. Morin \& P. A. Chambers, 2005. Bacteria and algae in stream periphyton along a nutrient gradient. Freshwater Biology 50: 1337-1350 doi:10.1111/j.1365-2427.2005.01401.x.

Clark, J. R., K. L. Dickson \& J. Cairns, 1979. Estimating aufwuchs biomass. In Weitzel, R. L. (ed) Methods and

Dills, G. \& D. T. Rogers, 1974. Macroinvertebrate community structure as an indicator of acid mine pollution. Environmental Pollution 6: 239-262.

Dodds, W. K., J. R. Jones \& E. B. Welch, 1998. Suggested classification of stream trophic state: distributions of temperate stream types by chlorophyll, total nitrogen, and phosphorus. Water Research 32: 1455-1462. 
Dsa, J. V., K. S. Johnson, D. Lopez, C. Kanuckel \& J. Tumlinson, 2008. Residual toxicity of acid mine drainage-contaminated sediment to stream macroinvertebrates: relative contribution of acidity vs. metals. Water, Air \& Soil Pollution 194: 185-197 doi:10.1007/s11270-008-9707-y.

Emerson, D., E. J. Fleming \& J. M. McBeth, 2010. Iron-oxidizing bacteria: an environmental and genomic perspective. Annual Review of Microbiology 64: 561-83 doi:10.1146/annurev.micro.112408.134208.

Garson, G. D., 2013. Generalized linear models/generalized estimating equations. Statistical Associates Publishing, Asheboro, NC.

Gerhardt, A., 1992. Effects of subacute doses of iron (Fe) on Leptophlebia marginata (Insecta: Ephemeroptera). Freshwater Biology 27: 79-84.

Gerhardt, A., 1993. Review of impact of heavy metals on stream invertebrates with special emphasis on acid conditions. Water, Air \& Soil Pollution 66: 289-314.

Ghiorse, W. C., 1984. Biology of iron- and manganese-depositing bacteria. Annual Review of Microbiology 38: 515-550.

Greenfield, J. P. \& M. P. Ireland, 1978. A survey of the macrofauna of a coal-waste polluted Lancashire fluvial system. Environmental Pollution 16: 105-122.

Hickey, C. W. \& W. H. Clements, 1998. Effects of heavy metals on benthic macroinvertebrate communities in New Zealand streams. Environmental Toxicology and Chemistry 17: 2338-2346.

Hill, B. H., W. T. Willingham, L. P. Parrish \& B. H. McFarland, 2000. Periphyton community responses to elevated metal concentrations in a Rocky Mountain stream. Hydrobiologia 428: 161-169.

Hirst, H., I. Jüttner \& S. J. Ormerod, 2002. Comparing the responses of diatoms and macroinvertebrates to metals in upland streams of Wales and Cornwall. Freshwater Biology 47: 1752-1765.

HMSO, 1978a. Iron in raw and potable waters by spectrophotometry (using 2, 4, 6-tripyridyl-1, 3, 5-triazine). Her Majesty’s Stationery Office, London.

HMSO, 1978b. Manganese in raw and potable waters by spectrophotometry (using formaldoxime). Her Majesty’s Stationery Office, London.

HMSO, 1980. Aluminium in raw and potable waters by spectrophotometry (using pyrocatechol violet). Her Majesty’s Stationery Office, London.

Hünken, A. \& M. Mutz, 2007. On the ecology of the filter-feeding Neureclipsis bimaculata (Trichoptera, Polycentropodidae) in an acid and iron rich post-mining stream. Hydrobiologia 592: 135-150 doi:10.1007/s10750-007-0735-1. 
Jarvis, A. P. \& P. L. Younger, 1997. Dominating chemical factors in mine water induced impoverishment of the invertebrate fauna of two streams in the Durham Coalfield, UK. Chemistry and Ecology 13: 249-270.

Kimball, B. A., R. L. Runkel, K. Walton-Day \& K. E. Bencala, 2002. Assessment of metal loads in watersheds affected by acid mine drainage using tracer injection and synoptic sampling: Cement Creek, Colorado, USA. Applied Geochemistry 17: 1183-1207.

Konhauser, K. O., 1998. Diversity of bacterial iron mineralization. Earth-Science Reviews 43: 91-121.

Lamberti, G. A. \& W. Moore, 1984. Aquatic insects as primary consumers. In Resh, V. H. \& D. M. Rosenberg (eds) The ecology of aquatic insects. Praeger, New York, 164-195.

Lamberti, G. A. \& V. H. Resh, 1985. Comparability of introducing tiles and natural substrates for sampling lotic bacteria, algae and macroinvertebrates. Freshwater Biolology 15: 21-30.

Layer, K., A. G. Hildrew \& G. Woodward, 2013. Grazing and detritivory in 20 stream food webs across a broad pH gradient. Oecologia 171: 459-471 doi:10.1007/s00442-012-2421-x.

Ledger, M. E. \& A. G. Hildrew, 1998. Temporal and spatial variation in the epilithic biofilm of an acid stream. Freshwater Biology 40: 655-670.

Ledger, M. E. \& A. G. Hildrew, 2000. Herbivory in an acid stream. Freshwater Biology 43: 545-556.

Ledger, M. E. \& A. G. Hildrew, 2005. The ecology of acidification and recovery: changes in herbivore-algal food web linkages across a stream pH gradient. Environmental Pollution 137: 103-11 doi:10.1016/j.envpol.2004.12.024.

Letterman, R. D. \& W. J. Mitsch, 1978. Impact of mine drainage on a mountain stream in Pennsylvania. Environmental Pollution 17: 53-73.

Macintosh, K. A. \& D. Griffiths, 2013. Catchment and in-stream influences on metal concentration and ochre deposit density in upland streams, Northern Ireland. Environmental Earth Sciences 70: 3023-3030 doi:10.1007/s12665-013-2363-6.

Macintosh, K. A. \& D. Griffiths, 2014. Spatial and temporal influences of in-stream factors on the chemistry and epilithic biomasses of upland stream metal deposits. Aquatic Sciences 76: 331-338 doi:10.1007/s00027-014-0338-7.

Magurran, A. E., 1988. Ecological diversity and its measurement. Chapman \& Hall, London.

Malmqvist, B. \& P. Hoffsten, 1999. Influence of drainage from old mine deposits on benthic macroinvertebrate communities in Central Swedish streams. Water Research 33: 2415-2423. 
Maltby, L. \& M. Crane, 1994. Responses of Gammarus pulex (Amphipoda, Crustacea) to metalliferous effluents: identification of toxic components and the importance of interpopulation variation. Environmental Pollution 84: 44-52.

Marker, A. F. H., C. A. Crowther \& R. J. M. Gunn, 1980. Methanol and acetone as solvents for estimating chlorophyll $a$ and phaeopigments by spectrophotometry. Archiv für Hydrobiologie Beiheft Ergebnisse der Limnologie 14: 52-69.

Mason, C. F., 1996. Biology of freshwater pollution, 3rd edn. Longman, Harlow.

Mayes, W. M., E. Gozzard, H. A. B. Potter \& A. P. Jarvis, 2008. Quantifying the importance of diffuse minewater pollution in a historically heavily coal mined catchment. Environmental Pollution 151: 165175 doi:10.1016/j.envpol.2007.02.008.

McCune, B. \& M. J. Mefford, 2006. PC-ORD. Multivariate Analysis of Ecological Data. MjM Software, Gleneden Beach, Oregon, U.S.A.

McKnight, D. M. \& G. L. Feder, 1984. The ecological effect of acid conditions and precipitation of hydrous metal oxides in a Rocky Mountain stream. Hydrobiologia 119: 129-138.

Mellanby, H., 1963. Animal life in fresh water, 6th edn. Chapman \& Hall, London.

Merritt, R. W. \& K. W. Cummins, 1996. An introduction to the aquatic insects of North America, 3rd edn. Kendall/Hunt Publishing Co, , Dubuque, Iowa.

Mihuc, T. B., 1997. The functional trophic role of lotic primary consumers: generalist var. specialist strategies. Freshwater Biology 37: 455-462.

Mulholland, P. J., C. T. Driscoll, J. W. Elwood, M. P. Osgood, A. V. Palumbo, A. D. Rosemond, M. E. Smith \& C. Schofield, 1992. Relationships between stream acidity and bacteria, macroinvertebrates, and fish: a comparison of north temperate and south temperate mountain streams, USA. Hydrobiologia 239: 7-24 doi:10.1007/BF00027525.

Murphy, J. \& J. P. Riley, 1958. A single-solution method for the determination of soluble phosphorus in sea water. Journal of the Marine Biological Association UK 37: 9-14.

Murphy, J. \& J. P. Riley, 1962. A modified single solution method for the determination of phosphate in natural waters. Analytica Chimica Acta 27: 31-36.

Neal, C., S. Lofts, C. D. Evans, B. Reynolds, E. Tipping \& M. Neal, 2008. Increasing iron concentrations in UK upland waters. Aquatic Geochemistry 14: 263-288 doi:10.1007/s10498-008-9036-1. 
Niyogi, D. K., D. M. McKnight \& W. M. Lewis, 1999. Influences of water and substrate quality for periphyton in a montane stream affected by acid mine drainage. Limnology and Oceanography 44: 804-809.

Nyberg, P., P. Andersson, E. Degerman, H. Borg \& E. Olofsson, 1995. Labile inorganic manganese - an overlooked reason for fish mortality in acidified streams? Water, Air and Soil Pollution 85: 333-340.

Peuranen, S., P. J. Vuorinen, M. Vuorinen \& A. Hollender, 1994. The effects of iron, humic acids and low pH on the gills and physiology of brown trout (Salmo trutta). Annales Zoologici Fennici 31: 389-396.

Pizarro, H. \& A. Vinocur, 2000. Epilithic biomass in an outflow stream at Potter Peninsula, King George Island, Antarctica. Polar Biology 23: 851-857.

Prange, H., 2007. Ochre pollution as an ecological problem in the aquatic environment: solution attempts from Denmark. Edmund Siemers-Stiftung, Hamburg.

Quinn, G. P. \& M. J. Keogh, 2002. Experimental design and data analysis for biologists. Cambridge University Press, Cambridge.

Rasmussen, K. \& C. Lindegaard, 1988. Effects of iron compounds on macroinvertebrate communities in a Danish lowland river system. Water Research 22: 1101-1108.

Rentz, J. A., I. P. Turner \& J. L. Ullman, 2009. Removal of phosphorus from solution using biogenic iron oxides. Water Research 43: 2029-2035 doi:10.1016/j.watres.2009.02.021.

Rice, E. W., R. B. Baird, A. E. Eaton \& L. S. Clesceri, 2012. Standard methods for the examination of water and wastewater, 22nd edn. American Public Health Association, Washington, D.C.

Roden, E. E., 2012. Microbial iron-redox cycling in subsurface environments. Biochemical Society Transactions 40: 1249-1256 doi:10.1042/BST20120202.

Rosemond, A. D., S. R. Reice, J. W. Elwood \& P. J. Mulholland, 1992. The effects of stream acidity on benthic invertebrate communities in the south-eastern United States. Freshwater Biology 27: 193-209.

Rosenberg, D. M. \& V. H. Resh (eds), 1993. Freshwater biomonitoring and benthic macroinvertebrates. Chapman \& Hall, New York.

Scullion, J. \& R. W. Edwards, 1980. The effects of coal industry pollutants on the macroinvertebrate fauna of a small river in the South Wales coalfield. Freshwater Biology 10: 141-162.

Sheldon, S. P. \& D. K. Skelly, 1990. Differential colonization and growth of algae and ferromanganesedepositing bacteria in a mountain stream. Journal of Freshwater Ecology 5: 475-485.

Sheldon, S. P. \& T. A. Wellnitz, 1998. Do bacteria mediate algal colonization in iron-enriched streams? Oikos 83: 85-92. 
Smock, L. A., 1983. The influence of feeding habits on whole-body metal concentrations in aquatic insects. Freshwater Biology 13: 301-311.

Stubblefield, W. A., S. F. Brinkman, P. H. Davies, T. D. Garrison, J. R. Hockett \& M. W. Mcintyre, 1997. Effects of water hardness on the toxicity of manganese to developing brown trout (Salmo trutta). Environmental Toxicology and Chemistry 16: 2082-2089.

Stumm, W. \& J. J. Morgan, 1996. Aquatic chemistry, 3rd edn. J Wiley \& Sons, New York.

Sutcliffe, D. W. \& A. G. Hildrew, 1989. Invertebrate communities in acid streams. In Morris, R., E. W. Taylor, D. J. A. Brown \& J. A. Brown (eds) Acid toxicity and aquatic animals. Society for Experimental Biology Seminar Series. Cambridge University Press, Cambridge, 13-29.

Tebo, B. M., J. R. Bargar, B. G. Clement, G. J. Dick, K. J. Murray, D. Parker, R. Verity \& S. M. Webb, 2004. Biogenic manganese oxides: properties and mechanisms of formation. Annual Review of Earth and Planetary Science 32: 287-328 doi:10.1146/annurev.earth.32.101802.120213.

Townsend, C. R., A. G. Hildrew \& J. Francis, 1983. Community structure in some southern English streams: the influence of physicochemical factors. Freshwater Biology 13: 521-544.

Verb, R. G. \& M. L. Vis, 2000. Comparison of benthic diatom assemblages from streams draining abandoned and reclaimed coal mines and nonimpacted sites. Journal of the North American Benthological Society 19: 274-288.

Verberk, W. C. E. P., P. J. J. van den Munckhof \& B. J. A. Pollux, 2012. Niche segregation in two closely related species of stickleback along a physiological axis: explaining multidecadal changes in fish distribution from iron-induced respiratory impairment. Aquatic Ecology 46: 241-248 doi:10.1007/s10452-012-9395-y.

Vuori, K.-M., 1995. Direct and indirect effects of iron on river ecosystems. Annales Zoologici Fennici 32: 317329.

Weitzel, R. L., S. L. Sanocki \& H. Holecek, 1979. Sample replication of periphyton collected from artificial substrates. In Weitzel, R. L. (ed) Methods and measurements of periphyton communities. American Society for Testing and Materials, Philadelphia, 90-115.

Wellnitz, T. A., K. A. Grief \& S. P. Sheldon, 1994. Response of macroinvertebrates to blooms of irondepositing bacteria. Hydrobiologia 281: 1-17.

Wellnitz, T. A. \& S. P. Sheldon, 1995. The effects of iron and manganese on diatom colonization in a Vermont stream. Freshwater Biology 34: 465-470. 
460 Withers, P. J. A. \& H. P. Jarvie, 2008. Delivery and cycling of phosphorus in rivers: A review. Science of the 461 Total Environment 400: 379-395 doi:10.1016/j.scitotenv.2008.08.002.

462 Woodcock, T. S. \& A. D. Huryn, 2005. Leaf litter processing and invertebrate assemblages along a pollution 463 gradient on a Maine (USA) headwater stream. Environmental Pollution 134: 363-375.

464 Younger, P. L., 2001. Mine water pollution in Scotland: nature, extent and preventative strategies. Science of 465 the Total Environment 265: 309-326.

466

467 
469 Table 1 Annual medians and ranges of deposit and biotic variables across the eight study sites.

470

\begin{tabular}{|c|c|c|}
\hline Variable & Median & Range \\
\hline $\mathrm{pH}$ & 6.7 & $4.6-8.7$ \\
\hline DO (\%) & 105.2 & 93.6-116.5 \\
\hline Deposit density $\left(\mathrm{g} \mathrm{m}^{-2}\right.$ ) & 58.5 & 10.3-883.6 \\
\hline $\mathrm{IM}\left(\mathrm{g} \mathrm{m}^{-2}\right)$ & 40.6 & $6.5-618.6$ \\
\hline $\mathrm{OM}\left(\mathrm{g} \mathrm{m}^{-2}\right)$ & 18.4 & $1.5-265.0$ \\
\hline Chla $\left(\mathrm{g} \mathrm{m}^{-2}\right)$ & 0.0056 & $0.0002-0.2691$ \\
\hline Autotrophic index & 3101 & $70-389513$ \\
\hline Ephemeroptera $\left(\mathrm{m}^{-2}\right)$ & 68 & $4-784$ \\
\hline Plecoptera $\left(\mathrm{m}^{-2}\right)$ & 52 & $4-384$ \\
\hline Trichoptera $\left(\mathrm{m}^{-2}\right)$ & 16 & $4-80$ \\
\hline Chironomidae $\left(\mathrm{m}^{-2}\right)$ & 12 & $4-256$ \\
\hline Lumbriculidae $\left(\mathrm{m}^{-2}\right)$ & 16 & $4-88$ \\
\hline Other invertebrates $\left(\mathrm{m}^{-2}\right)$ & 16 & $0-168$ \\
\hline
\end{tabular}

471 
472 Table 2 Pearson correlations between the first three axes of the CCA and deposit (d) variables (interset) and the 473 abundances of the main invertebrate taxa. Significant values $(P<0.01)$ are shown in bold. $n=80$.

474

\begin{tabular}{|c|c|c|c|c|c|c|c|}
\hline Variable & 1 & 2 & 3 & Taxon & 1 & 2 & 3 \\
\hline$\%$ DO & -0.23 & 0.34 & -0.10 & Lumbriculid & 0.72 & -0.14 & 0.09 \\
\hline Temperature & 0.13 & -0.37 & -0.25 & Gammarid & -0.06 & -0.33 & 0.35 \\
\hline $\mathrm{pH}$ & -0.11 & -0.16 & 0.06 & Leuctrid & -0.38 & 0.19 & -0.44 \\
\hline $\mathrm{Fe}_{\mathrm{d}}\left(\log _{10}\right)$ & 0.73 & 0.11 & 0.21 & Nemourid & -0.43 & 0.22 & -0.28 \\
\hline$M n_{d}\left(\log _{10}\right)$ & 0.56 & -0.05 & 0.37 & Perlid & -0.34 & 0.48 & 0.42 \\
\hline $\mathrm{Al}_{\mathrm{d}}\left(\log _{10}\right)$ & 0.30 & 0.02 & -0.09 & Perlodid & -0.37 & 0.17 & 0.22 \\
\hline$P_{d}\left(\log _{10}\right)$ & 0.72 & 0.37 & -0.03 & Baetid & -0.22 & -0.67 & -0.03 \\
\hline $\mathrm{IM}_{\mathrm{d}}\left(\log _{10}\right)$ & 0.53 & 0.00 & 0.06 & Ephemerellid & -0.21 & -0.38 & -0.12 \\
\hline Algal biomass $\left(\log _{10}\right)$ & -0.10 & 0.08 & -0.44 & Heptageniid & -0.27 & -0.38 & -0.21 \\
\hline NPD biomass $\left(\log _{10}\right)$ & 0.64 & 0.16 & 0.15 & Hydropsychid & -0.13 & -0.37 & -0.04 \\
\hline Number of taxa & -0.40 & -0.55 & 0.09 & Polycentropid & -0.27 & -0.19 & 0.16 \\
\hline Number of individuals $\left(\log _{10}\right)$ & -0.24 & -0.46 & -0.24 & Sericostomatid & -0.43 & -0.27 & 0.06 \\
\hline Shannon index & -0.33 & 0.00 & 0.20 & Chironomid & 0.30 & -0.15 & -0.38 \\
\hline Berger-Parker index & 0.25 & -0.20 & -0.14 & Simuliid & 0.06 & -0.04 & -0.34 \\
\hline ASPT & -0.88 & 0.22 & 0.02 & Tipulid & -0.01 & -0.46 & 0.06 \\
\hline
\end{tabular}


476 Table 3 Slope coefficients of generalized estimating equation outputs with (a) log. deposit density and (b) log.

477 deposit phosphorus concentration as the predictor variable for quadratic ( $\mathrm{x}$ and $\mathrm{x} 2)$ and linear models. $\Delta \mathrm{QICC}$ is

478 the absolute difference in QICC values for quadratic and linear models: slope coefficients are shown only for the 479 better model i.e. the one with the smaller QICC value.

480

\begin{tabular}{|c|c|c|c|c|}
\hline \multirow[b]{2}{*}{ Variable } & \multicolumn{2}{|c|}{ Quadratic } & \multirow{2}{*}{$\begin{array}{c}\text { Linear } \\
\text { x }\end{array}$} & \multirow[t]{2}{*}{$\triangle \mathrm{QICC}$} \\
\hline & $\mathrm{x}$ & $x^{2}$ & & \\
\hline \multicolumn{5}{|l|}{ (a) $x=$ Deposit density } \\
\hline Autotrophic index $\left(\log _{10}\right)$ & $-0.401 \pm 0.609$ & $0.759 \pm 0.313 *$ & & 1.22 \\
\hline Algal biomass $\left(\log _{10}\right)$ & $1.660 \pm 0.629 * *$ & $-0.856 \pm 0.324 * *$ & & 2.09 \\
\hline NPD biomass $\left(\log _{10}\right)$ & & & $1.126 \pm 0.049 * * *$ & 1.99 \\
\hline ASPT & $2.307 \pm 1.005 *$ & $-2.079 \pm 0.517 * * *$ & & 22.13 \\
\hline Number of taxa & $3.713 \pm 1.608 *$ & $-2.862 \pm 0.827 * * *$ & & 43.74 \\
\hline Number of individuals $\left(\log _{10}\right)$ & & & $-0.208 \pm 0.083 *$ & 1.60 \\
\hline Shannon (richness) & & & $-0.194 \pm 0.083 *$ & 0.96 \\
\hline Berger-Parker (dominance) & & & $0.039 \pm 0.033$ & 1.95 \\
\hline \multicolumn{5}{|l|}{ (b) $\mathrm{x}=$ Deposit phosphorus } \\
\hline Algal biomass $\left(\log _{10}\right)$ & $-3.475 \pm 1.203^{* *}$ & $-1.107 \pm 0.361 * *$ & & 3.31 \\
\hline NPD biomass $\left(\log _{10}\right)$ & & & $1.043 \pm 0.094 * * *$ & 1.78 \\
\hline
\end{tabular}


483 Table 4 Path analysis summaries of the effects of inorganic matter, NPD and algal biomass densities on

484 invertebrate richness, abundance, diversity and biotic scores. The values are path coefficients. U are unexplained 485 path effects $\left(=\sqrt{ }\left(1-r^{2}\right)\right) \cdot n=75$

486

\begin{tabular}{|c|c|c|c|c|}
\hline & & Direct & Indirect & Total \\
\hline \multirow{4}{*}{ Number of taxa } & IM & 0.100 & $-0.461 *$ & $-0.361^{*}$ \\
\hline & NPD & $-0.555^{*}$ & 0.011 & $-0.454^{*}$ \\
\hline & Algae & 0.199 & $0.370 *$ & -0.171 \\
\hline & $\mathrm{U}$ & 0.866 & & \\
\hline \multirow[t]{4}{*}{ Number of individuals $\left(\log _{10}\right)$} & IM & 0.149 & $-0.398 *$ & $-0.249 *$ \\
\hline & NPD & $-0.506 *$ & 0.157 & $-0.349 *$ \\
\hline & Algae & $0.366^{*}$ & -0.019 & $0.347^{*}$ \\
\hline & $\mathrm{U}$ & 0.856 & & \\
\hline \multirow[t]{4}{*}{ Shannon } & IM & 0.149 & $-0.422 *$ & $-0.273^{*}$ \\
\hline & NPD & $-0.496 *$ & 0.135 & $-0.361 *$ \\
\hline & Algae & 0.111 & -0.019 & 0.092 \\
\hline & $\mathrm{U}$ & 0.922 & & \\
\hline \multirow[t]{4}{*}{ Berger-Parker $\left(\log _{10}\right)$} & IM & -0.213 & $0.362 *$ & 0.149 \\
\hline & NPD & 0.418 & -0.187 & $0.231 *$ \\
\hline & Algae & -0.026 & 0.005 & -0.021 \\
\hline & $\mathrm{U}$ & 0.967 & & \\
\hline \multirow[t]{4}{*}{ ASPT } & IM & -0.125 & $-0.377^{*}$ & $-0.502 *$ \\
\hline & NPD & $-0.460 *$ & -0.094 & $-0.554^{*}$ \\
\hline & Algae & $0.209 *$ & -0.047 & 0.162 \\
\hline & $\mathrm{U}$ & 0.805 & & \\
\hline
\end{tabular}


489

490

Fig. 1 Biplot of CCA ordination of taxon (LC scores) and deposit variables (bold) across the first two axes.

491

492 Fig. 2 (a) Algal (circles) and NPD biomasses (triangles) (b) ASPT (circles) and the number of taxa (triangles)

493 and (c) the Shannon (circles) and Berger-Parker (triangles) indices as functions of deposit density. Lowess

494 smoothed lines (tension 0.7) are shown.

495

496 Fig. 3 Diagram showing path coefficients between the deposit components and total invertebrate abundance.

497 Heavy lines indicate significant coefficients. The coefficients for the predictor variables are the Pearson

498 correlation coefficients between these variables. 


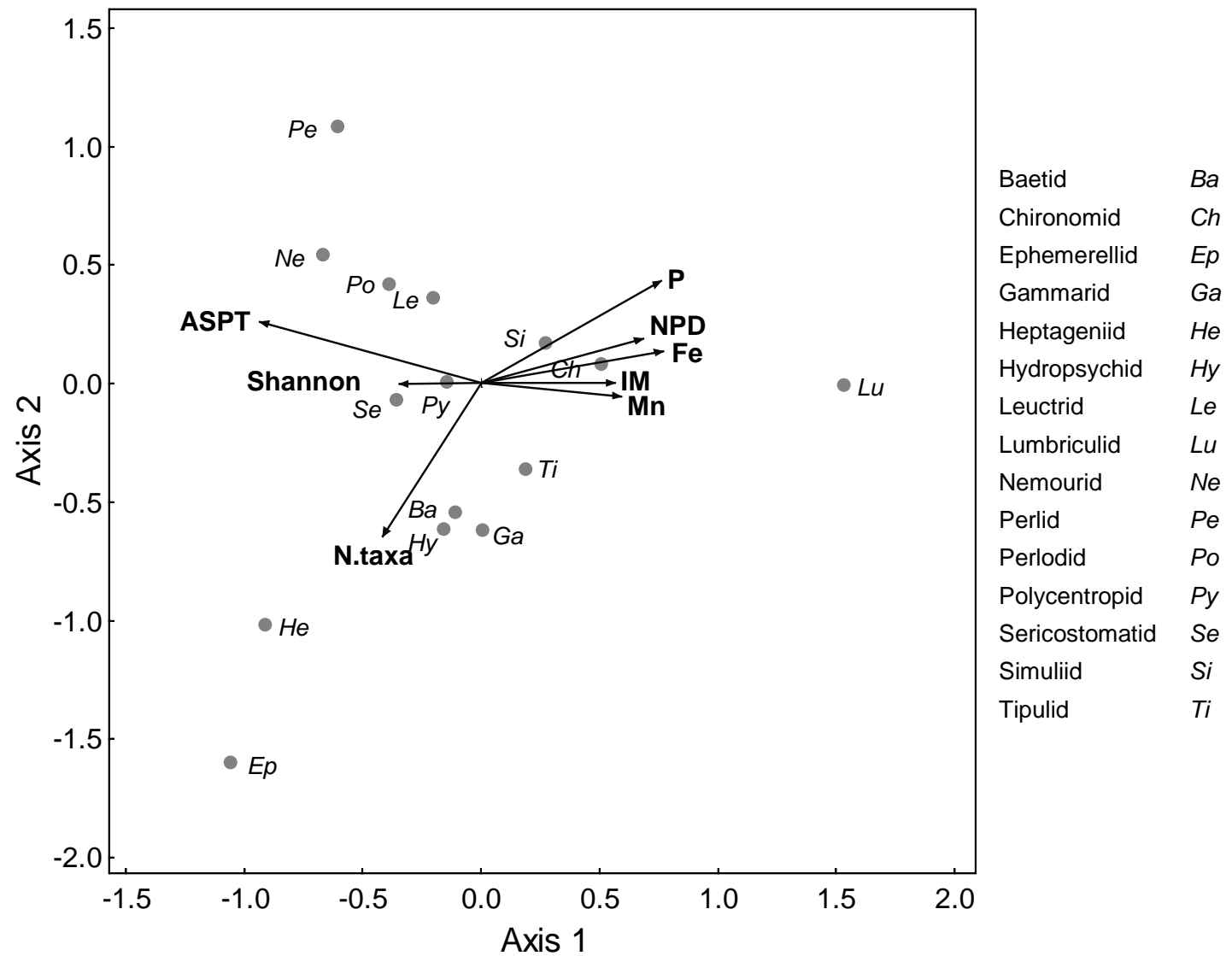

514

$515 \quad$ Fig. 1 


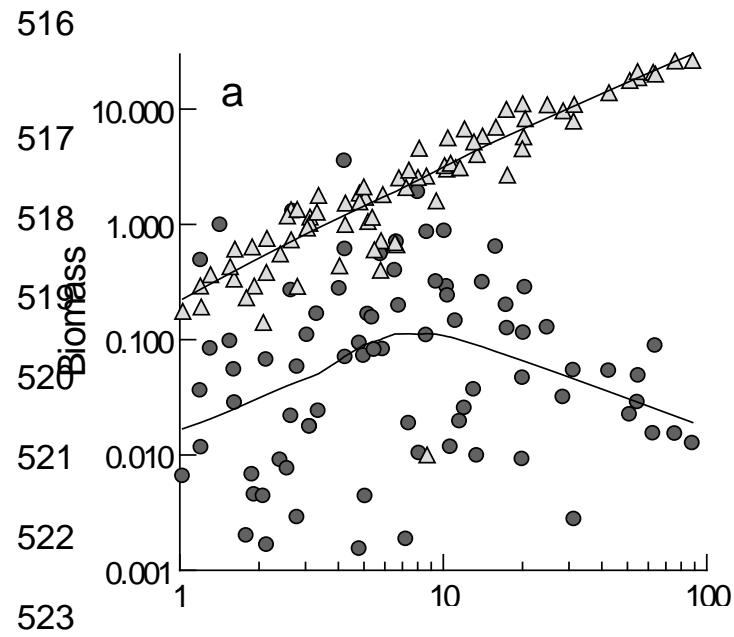

524 Fig. 2
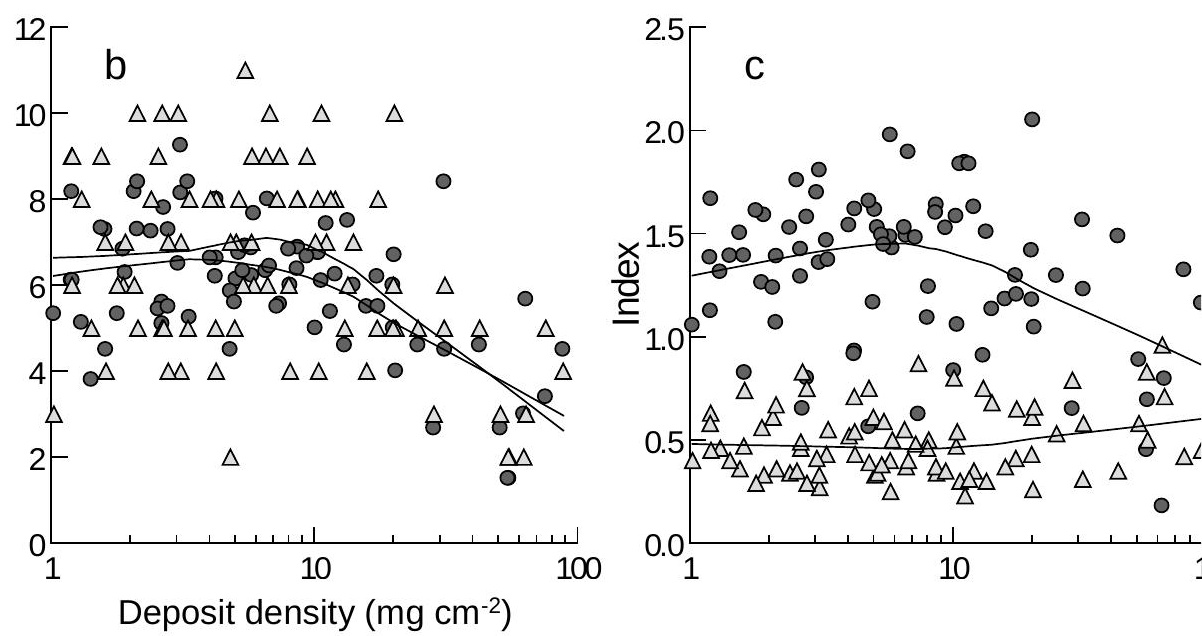


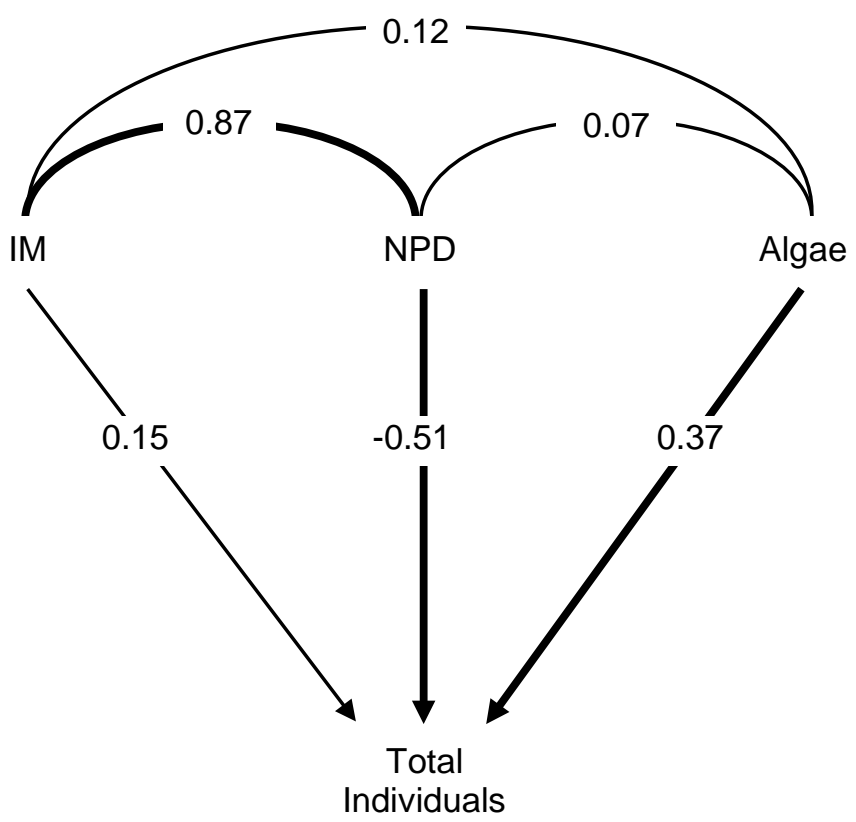

536

\section{Individuals}

537 Fig. 3

538

539 
540 Online Resource 1

541 Changes in epilithic biomasses and invertebrate community structure over a deposit metal concentration

542 gradient in upland headwater streams

543

544 Hydrobiologia

545

546 Katrina Ann Macintosh ${ }^{\mathrm{a}, *}$. David Griffiths ${ }^{\mathrm{a}}$

547 a School of Environmental Sciences, University of Ulster, Coleraine, U.K. BT52 1SA

548

549 E-mail address: ka.macintosh@ulster.ac.uk

550

551

552

553

554

555

556

557

558

559

560

561

562

563

564

565

566

567

568

569 

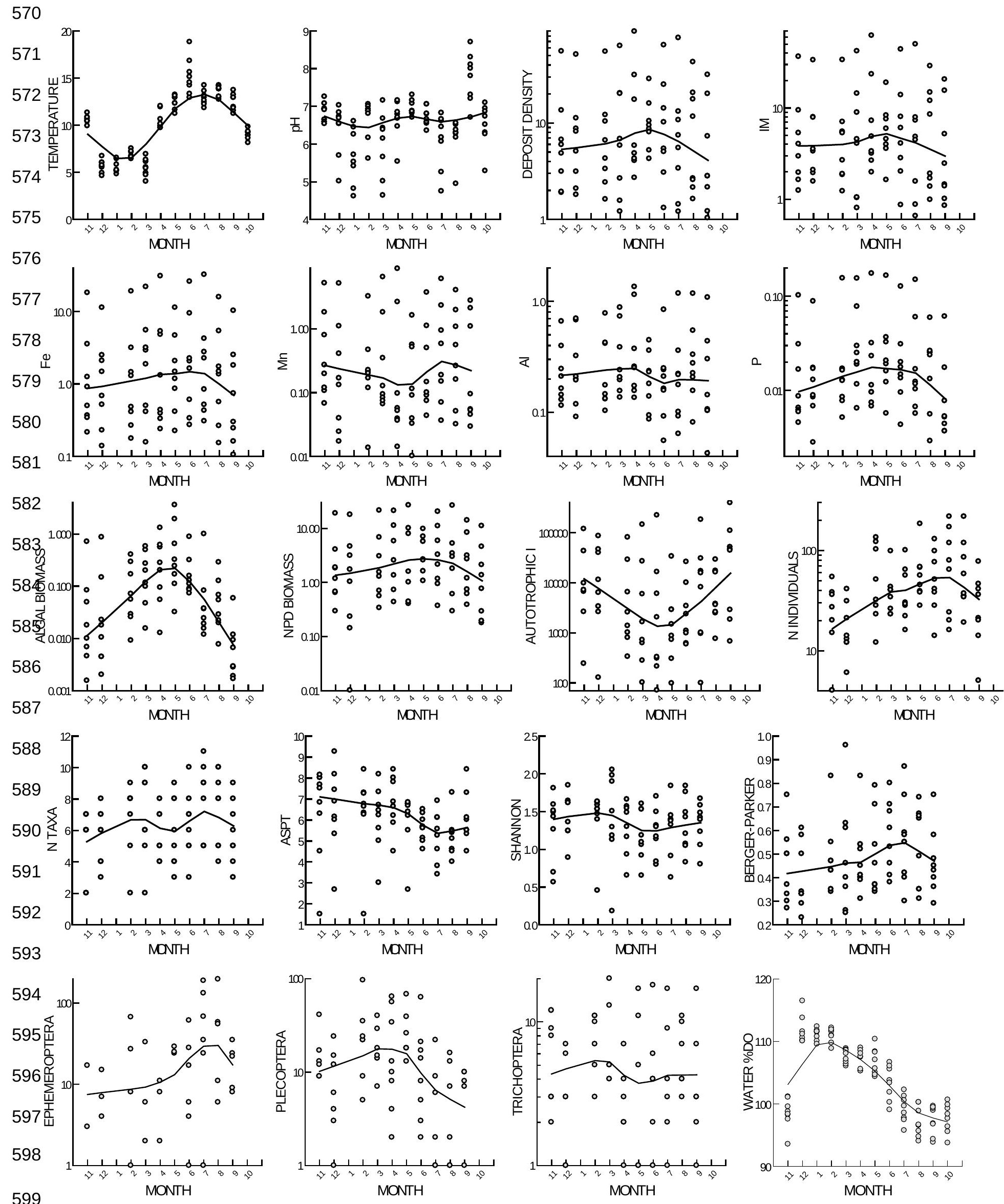
Fig. 1. Seasonal variation in physical, deposit chemical and biological variables, across all sites. The $\mathrm{x}$-axis is

601 ordered by calendar month, from November 2007 to October 2008. The lines are Lowess smoothers (tension 0.5). Note that some variables are log transformed. 